ON THE RECORD

'CThere's a perception that we don't bring much to the party.)

John LaMattina, of drug company Pfizer, laments the fact that only $9 \%$ of the US public believe the pharmaceutical industry is honest.

c(She's not under any pressure, she goes at her own steady pace... and is loved by everybody.")

A spokesman for Australia Zoo explains the longevity of Harriet the tortoise, believed to be the world's oldest animal, who just turned 175 .

Sources: New York Times, BBC News

\section{SCORECARD}

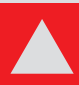
Minke whales Scientists have finally identified minke whales as the source of a mysterious 'boing' sound, first heard some 50 years ago in the North Pacific Ocean.

$\square$ Reality television British TV producers have created elaborate sets for a show - including speakers to play rocket noises, and decor from the film Space Cowboys - to con participants that they have been launched into space.

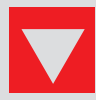

Trust

Support for President George W. Bush among US scientists and engineers has sunk to just $6 \%$, down from $30 \%$ four years ago.

\section{NUMBER CRUNCH}

Bat guano offers some surprising nutritional benefits compared with a Big Mac. Or at least, that's one possible reading of a study of the dietary habits of cave salamanders, which like to feast on the former.

\section{$54 \%$ of guano is protein.}

$23 \%$ of a Big Mac is protein.

$1 \%$ of guano is fat.

$33 \%$ of a Big Mac is fat.

Source: Fenolio, D. B. et al. Proc. R. Soc. Lond. B doi:10.1098/rspb.2005.3341 (2005).

\title{
Neuroscientists put gene therapy into reverse
}

\section{WASHINGTON DC}

Gene therapy has attracted plenty of fanfare but provided very little in terms of positive results. Giving people new genes to remedy defects in their old ones turns out to be a difficult business. But solid if little-noticed progress is being made in an approach that turns the concept on its head: rather than curing conditions, researchers are finding ways to study brain disease by inserting faulty genes into healthy animals.

Several pioneers of the technique presented their latest results at this year's annual meeting of the Society for Neuroscience, held on 12-16 November in Washington DC. They say the animal models they have created are easier to make than those based on alternative methods, mimic human versions of disease better, and can be applied to a wider range of species. "They open up possibilities that other models don't allow," says Anders Bjorklund, a specialist in neural transplantation at the University of Lund in Sweden.

Some of the most well-developed models are for Huntington's disease, a fatal movement disorder caused by a single faulty gene. The mutant gene expresses altered huntingtin protein, which results in damaged brain cells. One of the first Huntington animal models to be created by gene therapy was achieved in 2002 by Nicole Déglon of the Atomic Energy Commission in Orsay, France (J. Neurosci. 22, 3473-3483; 2002). Déglon injected a virus containing the faulty huntingtin gene into the striatum of rats. The virus inserted itself into neural DNA, causing expression of the huntingtin protein

\section{Seals net data from cold seas}

\begin{abstract}
Marine mammals are ready to start collecting data on the remote polar seas, say biologists. They have been tagging animals as part of their work for decades, and now they say the satellite tags are sophisticated enough to provide oceanographers with valuable data too.
\end{abstract}

Mike Fedak of the Sea Mammal Research Unit (SMRU) says he hopes the tags will bring together oceanographers and marine biologists. "One of the most exciting things is that we have something to talk about with oceanographers, and they actually want to hear it," he says.

The standard probes used by physical oceanographers are called CTDs, because they record conductivity, temperature and density. When dropped on lines or towed behind ships, they allow researchers to calculate the salinity and depth of the surrounding water, to track the distribution and movement of water masses.

The problem is that researchers are largely limited to areas where ships already travel. When it comes to the remote polar regions, especially the Antarctic, there is a dearth of data.

"There are a few floats out there but not much else," says Lars Bohme, an oceanographer who has been working with Fedak's team at the University of St Andrews, UK. "There's a need for real-time data from this area, to develop models that in the short term can help predict weather and in the long term, climate change."

Fedak and his colleagues worked with engineers at the SMRU to develop satellite tags containing miniaturized CTDs that can be carried by whales and seals. After a preliminary test on two beluga whales (Delphinapterus leucas) in Norway, a larger study called SEaOS (Southern elephant seals as Oceanographic Samplers) has convinced the researchers that the data are good enough to meet oceanographers' exacting standards.

The fist-sized tags were attached to the heads of about 70 elephant seals (Mirounga leonina) at four breeding areas around the Southern Ocean over the past three years.

During the Antarctic winter, the seals dive roughly 40 times a day to between 300 and 800 metres, to hunt for fish and squid. When the animal surfaces, data collected from its dive are transmitted to the Argos system of satellites. These relay the information to researchers in real time.

"The tags provide precise, accurate data," says Bohme. He is using information from SEaOS to profile the Southern Ocean's currents, and says he is now popular with other oceanographers, who are keen for data from the undersampled Southern Ocean.

"Oceanographers treated it 